\title{
Bioactive Heterometallic Cu"-Zn" Complexes with Potential Biomedical Applications
}

Ishani Majumder, ${ }^{\dagger}$ Prateeti Chakraborty, ${ }^{\ddagger}$ Raquel Álvarez, ${ }^{\S}$ Myriam Gonzalez-Diaz, ${ }^{\S}$ Rafael Peláez, ${ }^{\S}$

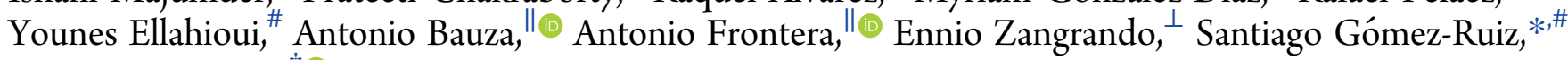
and Debasis Das ${ }^{*}{ }^{\dagger}$ (1)

${ }^{\dagger}$ Department of Chemistry, University of Calcutta, 92 A. P. C. Road, Kolkata 700009, India

${ }^{\ddagger}$ Department of Chemistry, Bangabasi College, 19, Rajkumar Chakraborty Sarani, Kolkata 700009, India

${ }^{\S}$ Department of Pharmaceutical Sciences, CIETUS and IBSAL, Faculty of Pharmacy, University of Salamanca, Campus Miguel de Unamuno, E-37007 Salamanca, Spain

"Departament de Química, Universitat de les Illes Balears, Crta. De Valldemossa km 7.5, 07122 Palma, Baleares, Spain

${ }^{\perp}$ Dipartimento di Scienze Chimiche, University of Trieste, Via L. Giorgieri 1, 34127 Trieste, Italy

\#Departamento de Biología y Geología, Física y Química Inorgánica, ESCET, Universidad Rey Juan Carlos, Calle Tulipán s/n, E-28933 Móstoles, Madrid, Spain

Supporting Information

ABSTRACT: A series of multinuclear heterometallic $\mathrm{Cu}-\mathrm{Zn}$ complexes of molecular formula $\left[(\mathrm{CuL})_{2} \mathrm{Zn}(\mathrm{dca})_{2}\right](\mathbf{1})$, $\left[(\mathrm{CuL})_{2} \mathrm{Zn}\left(\mathrm{NO}_{3}\right)_{2}\right] \quad(2), \quad\left[(\mathrm{CuL})_{2} \mathrm{Zn}_{2}(\mathrm{Cl})_{4}\right] \quad(3)$, and $\left[(\mathrm{CuL})_{2} \mathrm{Zn}_{2}\left(\mathrm{NO}_{2}\right)_{4}\right]$ (4) have been synthesized by reacting $[\mathrm{CuL}]$ as a "metalloligand $(\mathrm{ML})$ " (where $\mathrm{HL}=N, N^{\prime}$-bis $(5-$ chloro-2-hydroxybenzylidene)-2,2-dimethylpropane-1,3-diamine) and by varying the anions or coligands using the same molar ratios of the reactants. All of the four products including the ML have been characterized by infrared and UV-vis spectroscopies and elemental and single-crystal X-ray diffraction analyses. By varying the anions, different structures and topologies are obtained which we have tried to rationalize by means of thorough density

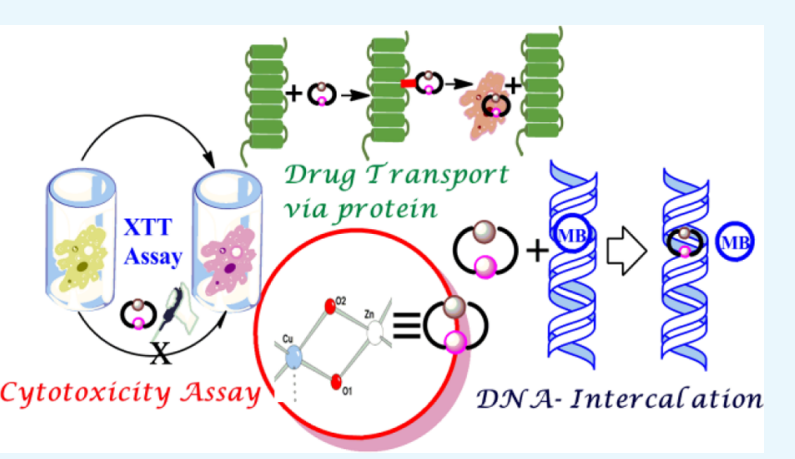
functional theory calculations. All of the complexes (1-4) have now been applied for several biological investigations to verify their therapeutic worth. First, their cytotoxicity properties were assessed against HeLa human cervical carcinoma along with the determination of $\mathrm{IC}_{50}$ values. The study was extended with extensive DNA and protein binding experiments followed by detailed fluorescence quenching study with suitable reagents to comprehend the mechanistic pathway. From all of these biological studies, it has been found that all of these heterometallic complexes show more than a few fold improvement of their therapeutic values as compared to the similar homometallic ones probably because of the simultaneous synergic effect of copper

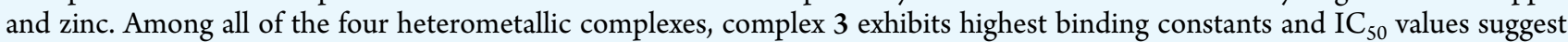
for their better interaction toward the biological targets and hence have better clinical importance.

\section{INTRODUCTION}

Metal complexes can be classified as simple organic ligandbound metal centers forming a precise three-dimensional arrangement. Therefore, synthesis of these transition-metal complexes can be easily done in just fewer steps with greater flexibility, attained by slight modification in each steps. Now, the specially designed metal complexes bearing suitable donor atoms can further be conveniently used as a "complex as a ligand"1-3 for the synthesis of multinuclear heterometallic complexes, one of the most attracted frameworks to structural chemists since the last two decades. The ongoing interest on heterometallic transition-metal complexes is principally owing to their miscellaneous applications ranging from catalytic activity, ${ }^{4}$ magnetic devices, ${ }^{5,6}$ and liquid crystalline materials ${ }^{7}$ to sensor design ${ }^{8}$ and finally, most importantly as therapeutic drugs. ${ }^{9,10}$ The common research in heterometallic chemistry majorly concentrates over molecular magnetism nurturing the strategy of single-molecule magnets leaving the biomedical application a less explored corner, although it may open up a new avenue in drug development. Thus, in the present perspective, we have therefore been motivated to develop heterometallic complexes having a potential therapeutic function. Although in the recent progress of medicinal research, huge applications have already been done using a

Received: June 6, 2018

Accepted: October 3, 2018

Published: October 17, 2018 
variety of homometallic complexes as metal-based therapeutic agents, ${ }^{11-15}$ leaving the heterometallic systems an untouched arena. To design the therapeutically active heterometallic complex, the goal in our mind was that the inclusion of two unlike cytotoxic metals in the same molecule would progress their biomedical activity as the interaction of two different metals with multiple biological targets may improve their physicochemical properties with respect to the homometallic one. Therefore, in this context, we have chosen to design heteronuclear complexes particularly comprising copper and zinc within the same ligand framework mainly because of this three principal reasons: (i) due to their mimicking ability like active site center in copper zinc superoxide dismutase. ${ }^{16,17}$ (ii) Many copper-containing complexes have possible medicinal value in curing various diseases including cancer. ${ }^{18,19}$ (iii) Zinc-containing complexes can exhibit awfully good activity toward the phosphate bond cleavage as it is in the active site center of phosphatase, which may therefore be utilized as a DNA-cleavage agent. ${ }^{20,21}$ Therefore, it has thought that their combination may advance their therapeutic value based on these abilities. In order to reach our goal, the ligand of our choice in the present study is $2,2^{\prime}-\left(\left(1 E, 1^{\prime} E\right)-((2,2\right.$-dimethylpropane-1,3-diyl)bis(azanylylidene))bis(methanylylidene))bis(4-chlorophenol), a tetradentate $\mathrm{N}, \mathrm{N}, \mathrm{O}, \mathrm{O}$ donor ligand, and first reacting it with copper(II) perchlorate, we obtained the mononuclear copper complex which is further used as the metalloligand (ML) to obtain the multinuclear heterometallic complexes in the presence of zinc salts by varying the anions. The four new heterometallic complexes $(1,2,3$, and 4$)$ so achieved illustrate anion-dependent structural variation which has been methodically characterized by X-ray diffraction studies, followed by thorough rationalization in terms of density functional theory (DFT) calculations. Finally, the heterometallic complexes have been applied to investigate their mode of action toward various biological processes to see their clinical importance. The detection abilities here include the first cytotoxicity study using $\mathrm{HeLa}$ cancer cells ${ }^{22}$ with the determination of $\mathrm{IC}_{50}$ values, suggesting that the compounds present a higher cytotoxic activity because of the synergic effect of both metal ions $\mathrm{Cu}$ and $\mathrm{Zn}$ than the similar homometallic complexes. Next, we have done the DNA-binding experiments with fish sperm DNA (FS-DNA), where complex 3 gives the highest binding constants; this study was further extended by fluorescence quenching with methylene blue $(\mathrm{MB})$ to get more insight on the intercalative mechanism. Finally, protein binding studies have been executed to evaluate the complexes' transporting ability as a drug using bovine serum albumin (BSA) as a carrier protein. The protein interaction was assessed by the tryptophan quenching study, and the corresponding binding constant and numbers of binding sites have been determined using complex 3 as the model. In particular, all of these synthesis, characterization, theoretical rationalization, and biological studies have been well documented in this paper.

\section{COMPUTATIONAL AND BIOLOGICAL DETAILS}

Theoretical Methods. BP86/def2TZVP has been applied to perform the calculations using the program TURBOMOLE version $7.0 .^{23}$ For reproducing the solvent effects, the conductor-like screening model COSMO, a variant of the dielectric continuum solvation models, ${ }^{24}$ has been employed.

Cytotoxicity Tests. Preparation of Solutions of Drugs. A stock solution of the compounds at a concentration of $2 \mathrm{mM}$ was prepared in dimethyl sulfoxide (DMSO), subsequently; the solution was diluted with water to various working concentrations. It is important to note that in no case, the quantity of DMSO in the solution was exceeding $0.5 \%$ to assure this is nontoxic to treated cells. DMSO was used because of the solubility problems. The nutrient medium was the Dulbecco's modified Eagle's medium, with phenol red, supplemented with L-glutamine $(2 \mathrm{mM})$, streptomycin (100 $\mu \mathrm{g} / \mathrm{mL})$, and penicillin $(100 \mathrm{U} / \mathrm{mL})$, and $10 \%$ fetal bovine serum. A Sodium 3'-[1-(phenylaminocarbonyl)-3,4-tetrazolium]-bis(4-methoxy-6-nitro)-benzenesulfonic acid hydrate (XTT) cell proliferation kit (Roche Molecular Biochemicals, Mannheim, Germany) was prepared according to the manufacturer's instructions. All reagents were purchased from Sigma Chemicals. For the normal cells, the CellTiterGlo 2.0 luminescent cell viability assay (Promega) was prepared according to the manufacturer's instructions.

Cell Culture. Human cervix adenocarcinoma HeLa cells were cultured as monolayers in the nutrient medium. The cells were grown at $37{ }^{\circ} \mathrm{C}$ in $5 \% \mathrm{CO}_{2}$ and humidified air atmosphere and were subsequently seeded (1500 cells per well) into 96-well microtiter plates, and $24 \mathrm{~h}$ later, after the cell adherence, different concentrations $\left(10^{-5}\right.$ to $\left.10^{-9} \mathrm{M}\right)$ of investigated compounds were added to the wells. Only the nutrient medium and DMSO were added to the cells in the control wells. Human bone marrow stroma cells [HS-5 (ATCC CRL-11882)] and human lung fibroblasts [MRC-5 (ATCC CCL-171)] were cultured as monolayers in the nutrient medium. The cells were grown at $37{ }^{\circ} \mathrm{C}$ in $5 \% \mathrm{CO}_{2}$ and humidified air atmosphere and were subsequently seeded (1500 cells per well) into 96-well microtiter plates, and $24 \mathrm{~h}$ later, after the cell adherence, different concentrations $\left(10^{-5}\right.$ to $10^{-9} \mathrm{M}$ ) of investigated compounds were added to the wells. Only the nutrient medium and DMSO were added to the cells in the control wells. All experiments were done in triplicate.

Determination of Target Cell Survival. Seventy-two hours after compound addition, cell survival was quantified using a XTT cell proliferation kit (Roche Molecular Biochemicals, Mannheim, Germany), following the instructions provided by the manufacturer. A mixture solution of the labeling reagent $\mathrm{XTT}$ and the electron-coupling reagent $\mathrm{N}$-methylphenaziniummethylsulfate was added to each well ( $50 \mu \mathrm{L}$ of each). The mixtures were incubated for $4 \mathrm{~h}$ in a humidified atmosphere $\left(37^{\circ} \mathrm{C}, 5 \% \mathrm{CO}_{2}\right)$, and as a formazan product is generated, the absorbance was measured with a microtiter plate reader at 450 $\mathrm{nm}$ using a reference wavelength of $630 \mathrm{~nm}$. The $\mathrm{IC}_{50}(50 \%$ inhibitory concentration) was calculated as the drug concentration causing a $50 \%$ inhibition of cell proliferation. For the normal cells $72 \mathrm{~h}$ after compound addition, cell survival was quantified using a CellTiter-Glo 2.0 luminescent cell viability assay (Promega), following the instruction of the manufacturer. The reactive $(50 \mu \mathrm{L})$ was added to each well, and the plate was shaken for $10 \mathrm{~s}$ and incubated at room temperature for $10 \mathrm{~min}$. The luminescence was measured with a VICTOR X3 multilabel plate reader, and as in the case of the HeLa cells, the $\mathrm{IC}_{50}$ ( $50 \%$ inhibitory concentration) was calculated as the drug concentration causing a $50 \%$ inhibition of cell proliferation.

Binding Experiments. DNA-Binding. FS-DNA was purchased from Sigma-Aldrich. The spectroscopic titration of FS-DNA was carried out in a Tris-amine buffer prepared at room temperature with the following composition $50 \mathrm{mM}$ $\mathrm{NaCl}-5 \mathrm{mM}$ Tris- $\mathrm{HCl}$ and which has a $\mathrm{pH}$ of 7.4. A solution 
Scheme 1. Formation of Complexes 1-4

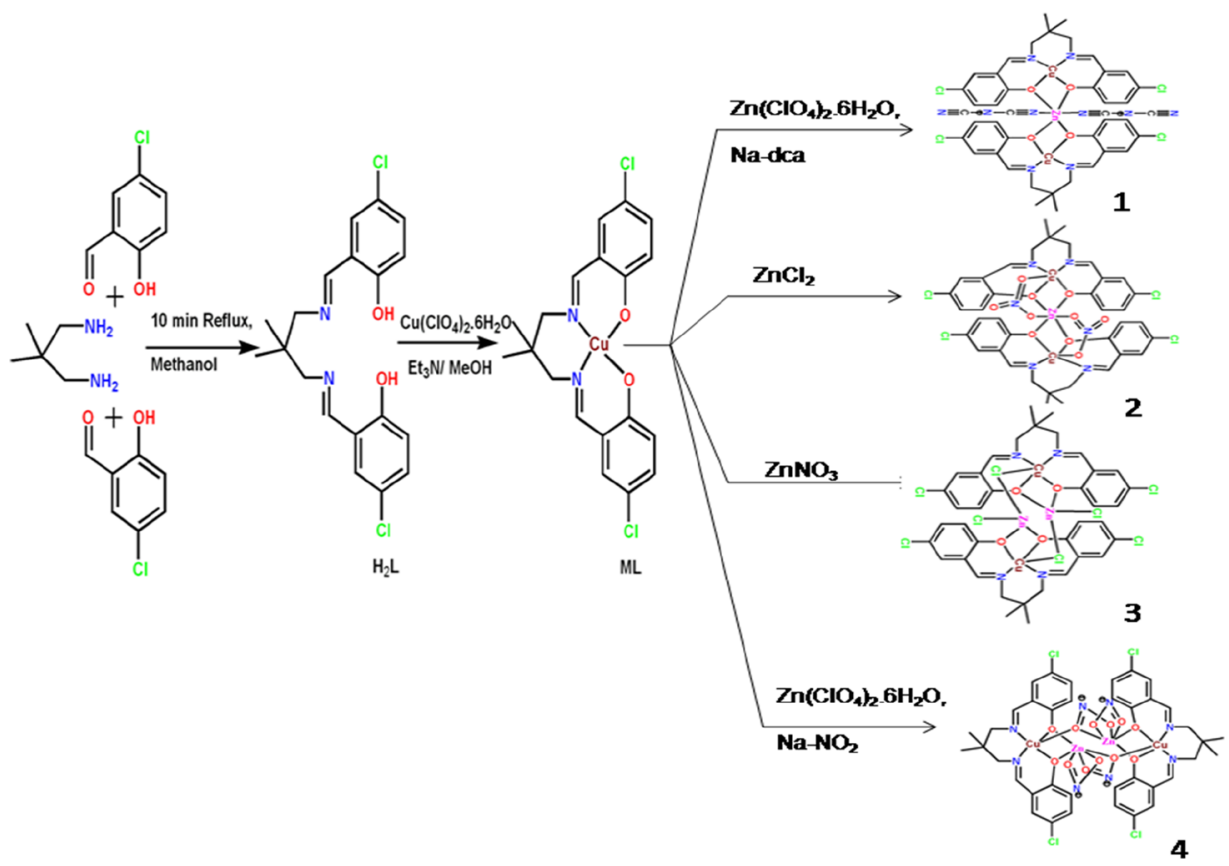

of FS-DNA in the buffer gave a ratio of UV absorbance 1.81.9:1 at 260 and $280 \mathrm{~nm}$, indicating that the DNA was sufficiently free of protein. ${ }^{25}$ Nanopure water was used to prepare the solutions, and the DNA concentration per nucleotide was determined by UV-visible spectroscopy using the known molar extinction coefficient value of $6600 \mathrm{M}^{-1} \mathrm{~cm}^{-1}$ at $260 \mathrm{~nm}^{26}$ Titrations were followed by absorption spectroscopy at $260 \mathrm{~nm}$ using fixed complex concentrations and adding increments of the DNA stock solution. ComplexDNA adduct solutions were incubated at $37{ }^{\circ} \mathrm{C}$ for $30 \mathrm{~min}$ before recording the absorption spectra.

BSA Interaction Studies. BSA was purchased from SigmaAldrich. The interaction of the synthesized materials with BSA was measured by absorption spectroscopy; the interaction studies were carried out at room temperature using the buffer with a composition of $50 \mathrm{mM} \mathrm{NaCl}-5 \mathrm{mM}$ Tris- $\mathrm{HCl}$ and a $\mathrm{pH}$ of 7.4. A solution of BSA in the buffer (using nanopure water to prepare the solutions) was used, and all of the spectroscopic studies were carried out between 200 and 500 $\mathrm{nm}$ by using a fixed concentration of complex and adding different quantities of BSA solution. The adducts formed by the metal complexes and BSA were incubated at $37{ }^{\circ} \mathrm{C}$ for 30 min before recording the UV-visible absorption spectra.

Tryptophan Quenching Experiment and Determination of Binding Constant and Number of Binding Sites. BSA fluorescence emission spectra have been recorded in the presence of increasing concentrations of the studied complex and in the absence of the studied complex to determine the possible interaction between the studied $\mathrm{Zn}-\mathrm{Cu}$ complex and BSA. It is generally agreed that the BSA fluorescence is coming from tryptophan (Trp), located on the surface of the domain, Trp-213 located in the hydrophobic pocket of domain II, and phenyl alanine (Phe) residues. In all cases, it is observed that BSA solutions have the fluorescence emission at $345 \mathrm{~nm}$ upon excitation at $285 \mathrm{~nm}$.

\section{RESULTS AND DISCUSSION}

Synthesis, Rationalization, and Characterization of the Metal Complexes. Four structurally characterized heterometallic complexes have been synthesized using the sequential procedure in which the methanolic solution of the zinc salts as the second metal is added to the methanolic solution of the $\mathrm{ML}[\mathrm{CuL}]$ (Scheme 1). In some cases (complexes 1 and 4), bridging salts $\left(\mathrm{dca}^{-}\right.$and $\mathrm{NO}_{2}^{-}$) are added to the heterometallic solution in order to obtain the coordination polymers.

FT-IR and UV-Visible Spectra of the Complexes. Fourier transform infrared spectroscopy (FT-IR) spectra of all of the four heterometallic complexes and the ML are presented in Figures $\mathrm{S} 1-\mathrm{S} 5$. The $\mathrm{ML}$ shows a $\mathrm{C}=\mathrm{N}$ stretching frequency at $1623 \mathrm{~cm}^{-1}$ and skeletal vibration at $1533 \mathrm{~cm}^{-1}$. For the heterometallic complexes, they all possess a band in the region of $1634-1647 \mathrm{~cm}^{-1}$ because of the azomethane $(\mathrm{C}=\mathrm{N})$ group and show skeletal vibration around $1520 \mathrm{~cm}^{-1}$. Complex 1 displays a sharp peak at $2150 \mathrm{~cm}^{-1}$ because of coordinated dicyanamide anion, whereas complex 2 exhibits a peak at $1379 \mathrm{~cm}^{-1}$, which is characteristic of nitrate. Complex 3 is a halide-containing species which therefore does not show any characteristic sharp peak for anions. Complex 4 is a nitritebridging species which hence displays a sharp peak at 1414 $\mathrm{cm}^{-1}$ characteristic of nitrite.

The absorption spectra of the complexes have been performed in the DMSO medium at room temperature and are shown in Figure S6. All of the complexes exhibit similar absorption spectra with an intense band at around $375 \mathrm{~nm}$ very similar to that of the ML, clearly indicating that here a ligandto-metal charge transfer occurs in the ML complexes which persists also in the presence of the $\mathrm{d}^{10}$ metal ion zinc.

Crystal Structure Description of the Complexes. Metalloligand. An ORTEP view of ML, used as the "ML" building unit for the synthesis of polynuclear complexes here described, is reported in Figure 1. A selection of bond lengths and angles is reported in Table S1. In the complex, the $\mathrm{Cu}^{\mathrm{II}}$ ion 


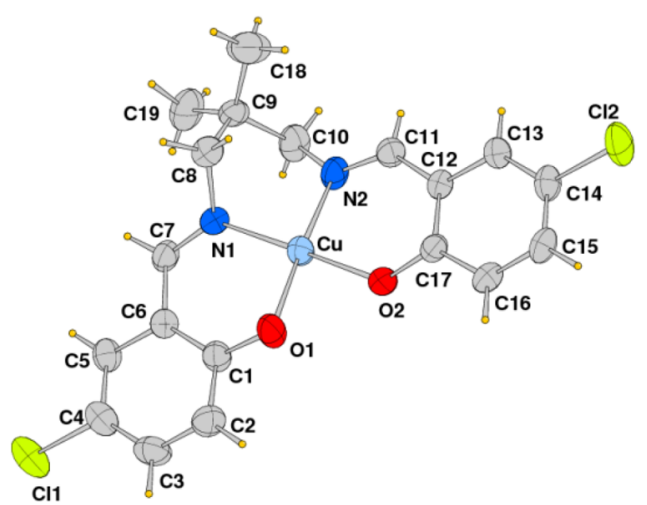

Figure 1. ORTEP drawing (ellipsoids at 50\% probability) of ML.

is coordinated in a slightly distorted square-planar environment by the $\mathrm{N}$ and $\mathrm{O}$ atoms of the tetradentate ligand. The complex atoms with the exception of the propyl chain are practically coplanar, and the dihedral angle between the salicylaldimine moieties is of $7.22^{\circ}$. The $\mathrm{Cu}-\mathrm{O}$ and $\mathrm{Cu}-\mathrm{N}$ bond distances are within the normal ranges being of 1.905(2) and 1.903(2) $\AA$ and of 1.947(3) and 1.953(3) $\AA$, respectively. The crystal packing shows complexes piled along axis $a$ alternatively in the head-tail fashion related to the center of symmetry. This arrangement allows the phenyl rings to be faced showing $\pi-\pi$ interactions (centroid-to-centroid distances of 3.828(2) and 3.838(2) A).

Complexes $\mathbf{1}$ and $\mathbf{2}$ are trinuclear species in which two $\mathrm{CuL}$ (ML) units bridge central $\mathrm{Zn}$ atom in a centrosymmetrical fashion, where the copper and zinc ions exhibit a square pyramidal and octahedral coordination geometry, respectively. A perspective view of the polymeric unit of complex $\mathbf{1}$ and that of complex 2 are shown in Figures 2 and 4, respectively.

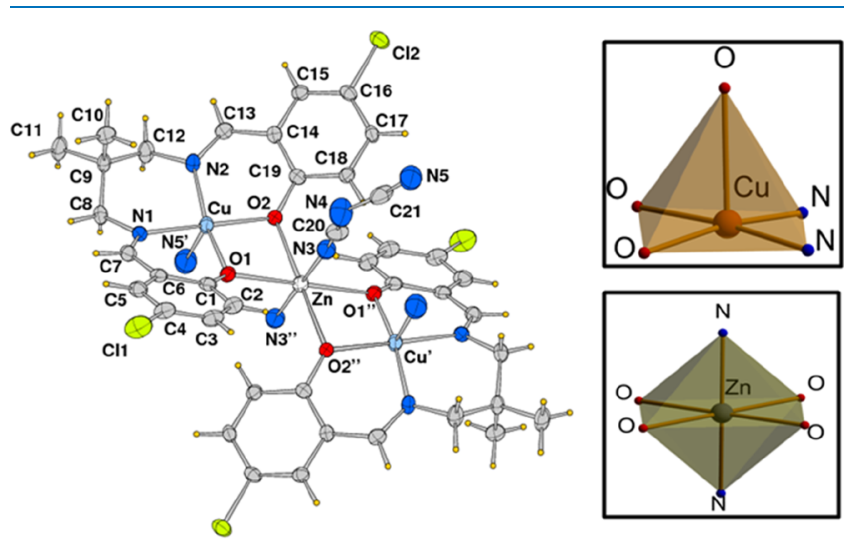

Figure 2. ORTEP drawing (ellipsoids at $35 \%$ probability) of the centrosymmetric unit of polymeric complex 1 (inset: coordination environment around $\mathrm{Cu}^{\mathrm{II}}$ and $\mathrm{Zn}^{\mathrm{II}}$ centers).

An ORTEP view of complex $\mathbf{1}$ is shown in Figure 2. Here, a pair of $\mu_{1,5}$-dicyanoamide anions bridges the zinc and copper ions of trinuclear units, thus forming a polymeric chain along crystallographic axis $c$, as depicted in Figure 2. The dicyanoamide has been used in trinuclear $\mathrm{Cu}-\mathrm{M}-\mathrm{Cu}$ similar complexes $(\mathrm{M}=\mathrm{Co}, \mathrm{Ni}$, and $\mathrm{Zn})$, obtaining a $2 \mathrm{D}$ polymeric network instead. ${ }^{27}$ Complex 1 shows the basal $\mathrm{Cu}-\mathrm{N}$ and $\mathrm{Cu}-\mathrm{O}$ bond distances following a trend similar to other complexes, whereas the apical $\mathrm{Cu}-\mathrm{N}(\mathrm{dca})$ is of $2.479(5) \AA$. The $\mathrm{Zn}-\mathrm{O}$ bond lengths, with a mean value of $2.180 \AA$, are ca.
0.1 longer than those measured in complex 2 , but $\mathrm{Zn}-\mathrm{N}(\mathrm{dca})$ is of 2.031(4) $\AA$. Thus, the $\mu_{1,5}-\mathrm{dca}$ connector exhibits an asymmetric coordination, which is more strongly bound to $\mathrm{Zn}$. The intermetallic $\mathrm{Cu}-\mathrm{Zn}$ distance within the trinuclear entity is of $3.1891(8) \AA$, and the dca spaces the metals along the chain at 8.9152(13) A (Figure 3).

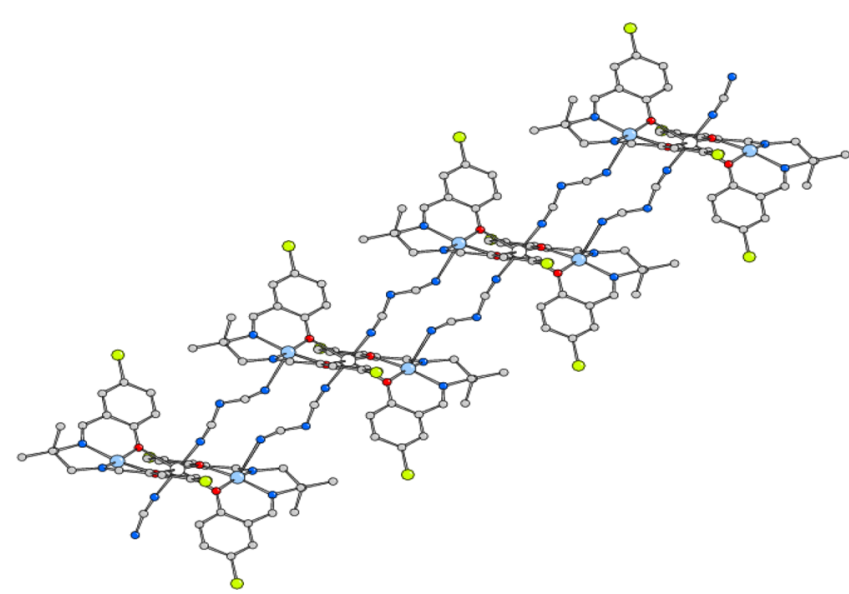

Figure 3. Polymeric structure of complex 4 developed along crystallographic axis $c$.

In the discrete complex 2 , the metals are bridged by two nitrate anion symmetry related to the center of inversion (Figure 4). Each anion is disordered over two positions at half

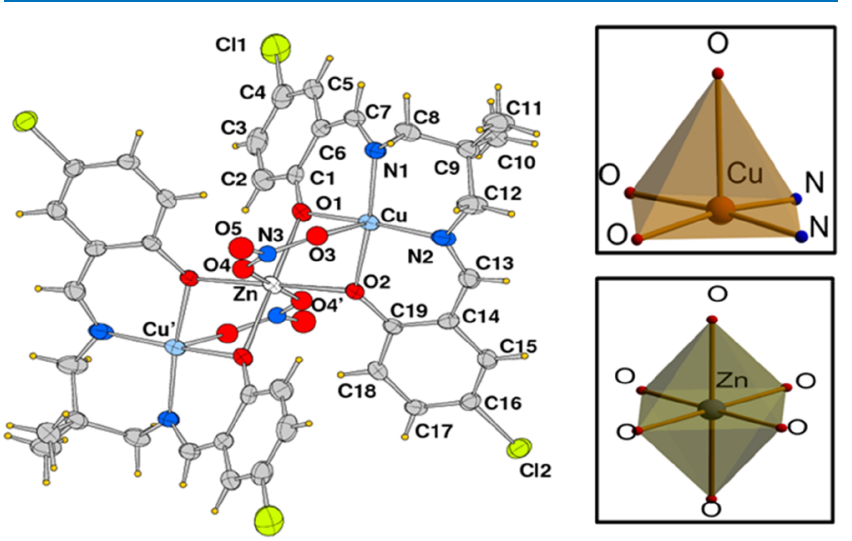

Figure 4. ORTEP drawing (ellipsoids at $35 \%$ probability) of centrosymmetric trinuclear complex 2 of the disordered bridging nitrate anion, only one fragment is shown (inset: coordination environment around $\mathrm{Cu}^{\mathrm{II}}$ and $\mathrm{Zn}^{\mathrm{II}}$ centers).

occupancy in order to avoid, for one of these steric clashes with a lattice water molecule O1w (occupancy 0.5). In the square pyramidal coordination geometry of copper, the basal $\mathrm{Cu}-\mathrm{O}$ and $\mathrm{Cu}-\mathrm{N}$ bond lengths are comparable to those detected in other compounds reported here. On the other hand, the apical position is occupied by disordered nitrate oxygens $\mathrm{O}(3)$ and $\mathrm{O}(3 \mathrm{~b})$ at 2.356(11) and 2.323(12) Å, respectively (Figure S7), considerably shorter than the $\mathrm{Cu}-\mathrm{O}$ (nitrite) value measured in 4 (of 2.593(3) $\AA$ ).

On the other hand, in the octahedral $\mathrm{ZnO}_{6}$ chromophore, the $\mathrm{Zn}-\mathrm{O}$ bond distances are in the range 2.045(3)2.084(10) $\AA$, but the distance involving oxygen $\mathrm{O}(4 \mathrm{~b})$, of the second nitrate fragment, is significantly longer $(2.279(11)$ $\AA)$. The intermetallic $\mathrm{Cu}-\mathrm{Zn}$ distance is of 3.0178(6) $\AA$. 
Three such linear $\mathrm{Cu}-\mathrm{Zn}-\mathrm{Cu}$ complexes containing bridging nitrate, ${ }^{28}$ acetate, $^{29}$ and azide ${ }^{30}$ with salicylidene-1,3propanediaminate have been reported, showing that a $\mathrm{Cu}-\mathrm{Zn}$ distance is of $3.0017(6) \AA$.

Different from what observed in the tetranuclear complexes where the phenol moieties of the ligand $\mathrm{L}$ are slightly tilted to each other here is worth noting the umbrella shape arrangement assumed by the symmetry related ligands $\mathrm{L}$ in order to allow the formation of the trinuclear $\mathrm{Cu}-\mathrm{Zn}-\mathrm{Cu}$ derivatives. This conformation (Figure 5) is such that the phenol rings form close comparable dihedral angles of $57.93^{\circ}$ and $59.98^{\circ}$, in complexes 1 and 2 , respectively.

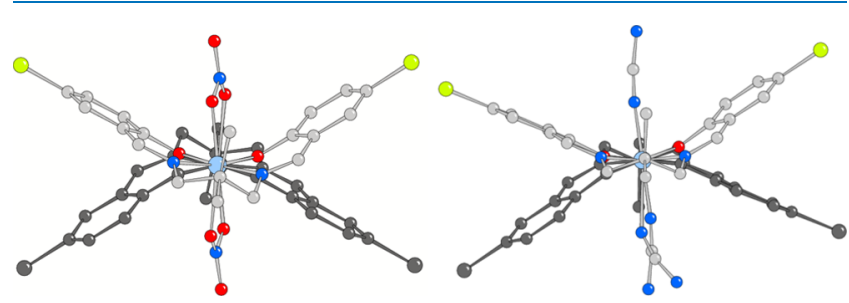

Figure 5. View along the $\mathrm{Cu}-\mathrm{Cu}^{\prime}$ direction in the trinuclear complexes $\mathbf{2}$ and $\mathbf{1}$, showing the conformational arrangement assumed by the two L ligands.

By using anions chloride or nitrite, we obtained tetranuclear $\mathrm{Cu}_{2} \mathrm{Zn}_{2}$ complexes, $[\mathrm{CuLZnCl}]_{2}$ (3) and $\left[\mathrm{CuLZn}\left(\mathrm{NO}_{2}\right)_{2}\right]_{2}$ (4). Both are structurally related and can be considered as a dimmer of two diphenoxo-bridged dinuclear CuLZn moieties connected by bridging $\mathrm{Cl}^{-}$or $\mathrm{NO}_{2}^{-}$anions in a centrosymmetric fashion, crystallizing in the monoclinic space group $P 2_{1} /$ c. An ORTEP diagram of the two complexes is shown in Figures 6 and 7, and the bond lengths and angles of the coordination sphere are listed in Tables S5 and S6, respectively.

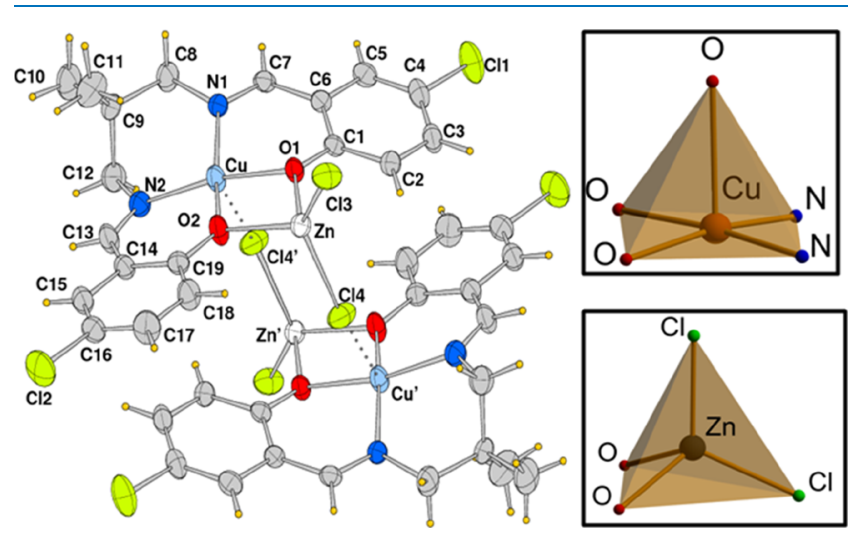

Figure 6. ORTEP drawing (ellipsoids at $40 \%$ probability) of centrosymmetric tetranuclear complex 3 (inset: coordination environment around $\mathrm{Cu}^{\mathrm{II}}$ and $\mathrm{Zn}^{\mathrm{II}}$ centers).

In complex 3, which as-mentioned above is closely related to 4, the geometry around copper is still in a distorted square pyramidal geometry with a $\tau$ parameter of 0.118 . Here, the $\mathrm{Cu}-\mathrm{N}$ and $\mathrm{Cu}-\mathrm{O}$ bond lengths are of $1.975(3)$ and 1.935(4) and 1.929(3) and 1.939(3) $\AA$, respectively. The apical position is occupied by chloride at considerably long distance $\mathrm{Cu}-$ $\mathrm{Cl}\left(4^{\prime}\right), 2.8484(15) \AA$, that however does not exclude an interaction between these atoms. On the other hand, the zinc ion possesses a distorted tetrahedral coordination sphere built

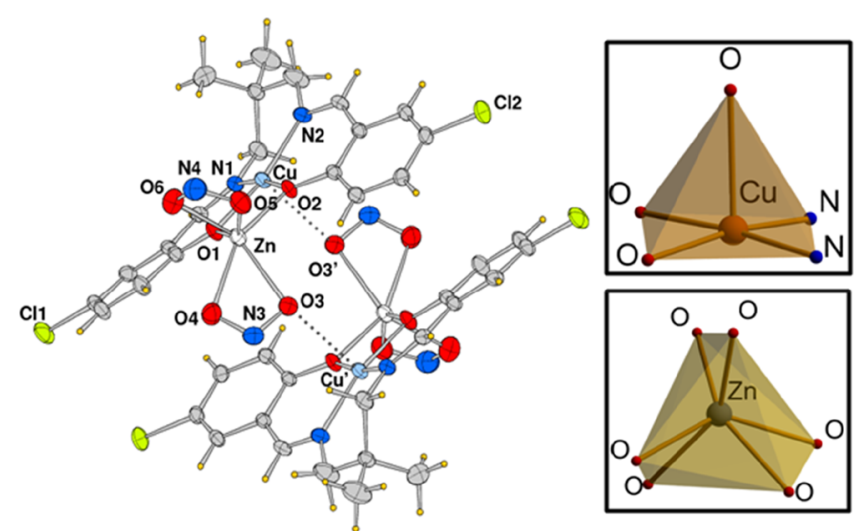

Figure 7. ORTEP drawing (ellipsoids at $40 \%$ probability) of centrosymmetric tetranuclear complex 4 (inset: coordination environment around $\mathrm{Cu}^{\mathrm{II}}$ and $\mathrm{Zn}^{\mathrm{II}}$ centers).

by the phenolate oxygens ( $\mathrm{Zn}-\mathrm{O}$ distances of $1.990(3)$ and $1.999(3) \AA$ ) and two chlorides ( $\mathrm{Zn}-\mathrm{Cl}$ of 2.1929(12) and 2.2057(12) ^). The coordination angles about $\mathrm{Zn}$ are in the range $110.56(10)-120.12(10)^{\circ}$ with the exception of $\mathrm{O}(1)-$ $\mathrm{Zn}-\mathrm{O}(2)$ of $76.56(11)^{\circ}$. The salicylaldimine moieties are tilted to form a dihedral angle of $23.30^{\circ}$.

In complex 4, the geometry around copper can be best described as a distorted square pyramidal geometry as indicated by the $\tau$ parameter value of 0.125 ( $\tau=0$ and 1 for a perfect square-pyramidal and trigonal bipyramidal geometry, respectively). ${ }^{31}$ The basal plane of the five-coordinated $\mathrm{Cu}$ ion consists of two amine nitrogen atoms $(\mathrm{Cu}-\mathrm{N}$ bond distances of $1.937(3)$ and $1.979(3) \AA)$ and two phenolic oxygens ( $\mathrm{Cu}-$ O bond distances 1.951(2) and 1.925(2) $\AA$ ), whereas the apical position is occupied by a bridging nitrite oxygen atom $\left(\mathrm{Cu}-\mathrm{O}\left(3^{\prime}\right)\right.$ of $2.593(3) \AA$ ). The two salicylaldimine moieties are tilted about the central copper atom, forming a dihedral angle of $23.95^{\circ}$. The zinc ion exhibits a distorted octahedral geometry in an $\mathrm{O}_{6}$ donor set realized by two bridging nitrite anions and by the phenolate oxygen atoms. The $\mathrm{Zn}-$ $\mathrm{O}$ (phenol) distances are 2.030(2) and 2.018(2) $\AA$, whereas $\mathrm{Zn}-\mathrm{O}$ (nitrite) is significantly longer in between 2.143(3) and 2.223(3) A. The deviations from the ideal octahedral geometry are clearly demonstrated by the coordination bond angles reported in Table S5; these vary from ca. $57^{\circ}$ for the bridging anions to $147.75(11)^{\circ}$.

It is worth noting the similarity in the arrangement of the metal atoms in the tetranuclear core (Figure 8). In fact, the $\mathrm{Cu}-\mathrm{Zn}$ and $\mathrm{Cu}-\mathrm{Zn}^{\prime}$ intermetallic distances are 3.0709(5) and

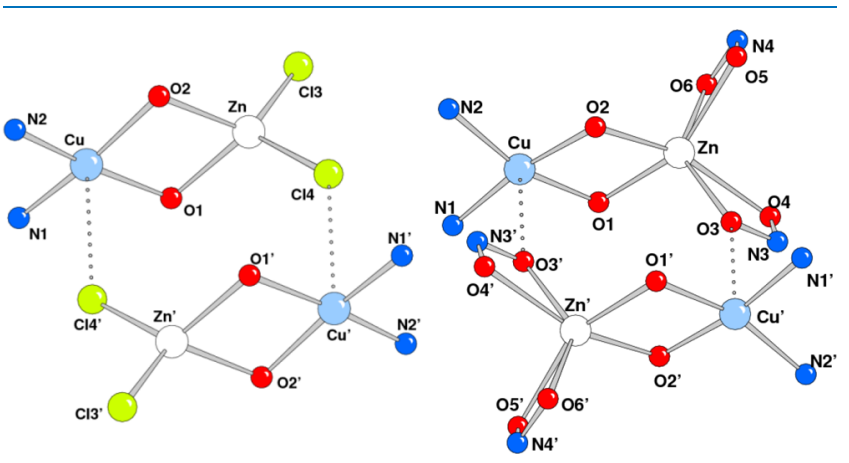

Figure 8. Arrangement of metal atoms in the tetranuclear core of complexes 3 and 4. 

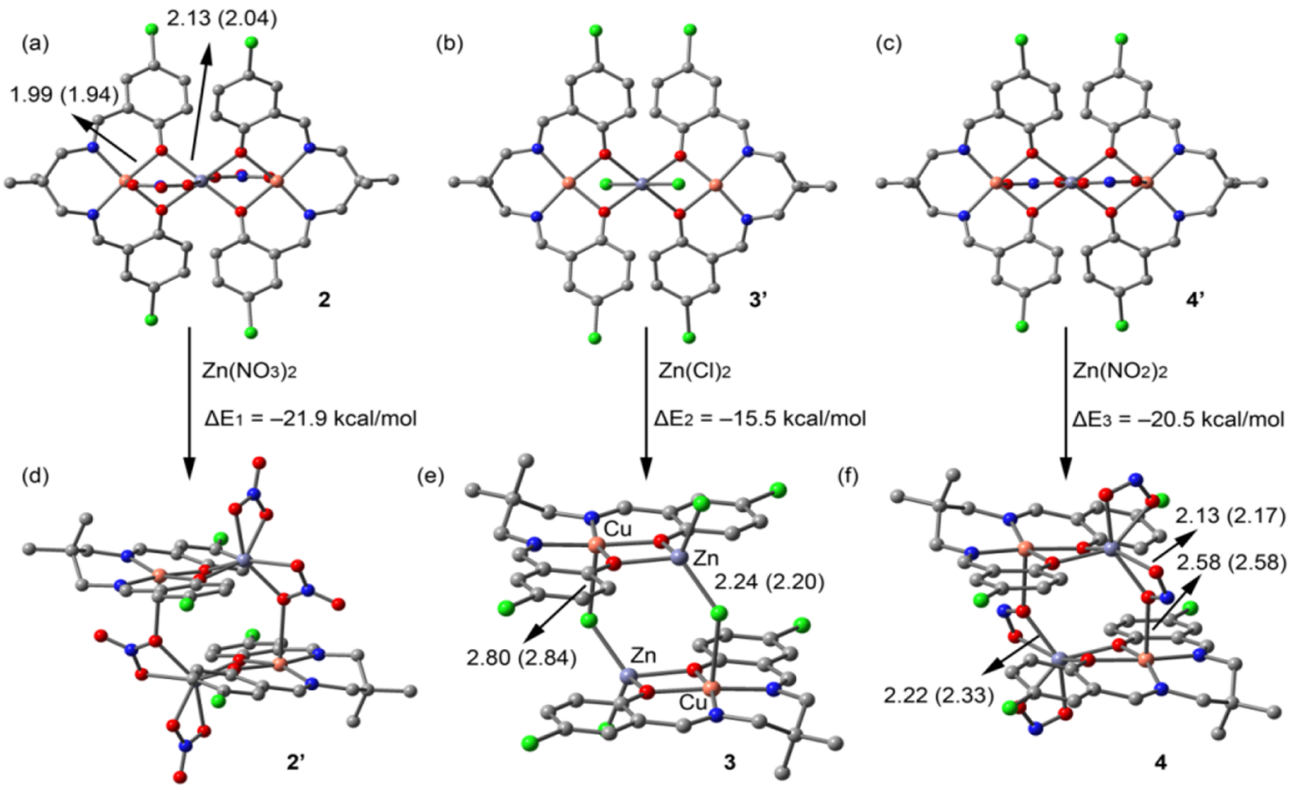

Figure 9. Optimized geometries of compounds $2-4$ (a,e,f, respectively) and their hypothetical complexes $\mathbf{2}^{\prime}-\mathbf{4}^{\prime}(\mathrm{d}, \mathrm{b}, \mathrm{c}$, respectively). Distances in A.

4.7024(5) A, respectively, in complex 4, to be compared with the corresponding figures in 3 of $3.0526(8)$ and $4.6117(8) \AA$, respectively.

Solution Studies: Mass Spectrometry. In order to determine the compositions of heteronuclear complexes essential to understand their solution chemistry, we have performed the mass spectral study in the DMSO-acetonitrile mixture. All of the mass spectra are given in the Supporting Information (Figures S9-S12). Complex 1 dissociates into two species with a base peak of $1063.0159 \mathrm{amu}\left(\left[\mathrm{CuL}_{2} \mathrm{Zn}\right.\right.$ (dca) $\left.\left(\mathrm{H}_{2} \mathrm{O}\right)\right]^{+}$, calcd $1063.9759 \mathrm{amu}$ ) and a small peak arising at $1015.0287 \mathrm{amu}$ (calcd $1091.9767 \mathrm{amu}$ ) responsible for the monocation $\left[\mathrm{CuL}_{2} \mathrm{Zn}\left(\mathrm{H}_{2} \mathrm{O}\right)_{2}\right]^{+}$. Complex 2 on the other hand displays only one peak, i.e., the base peak arising at 1043.6355 amu for the formation of the monocation $\left[\mathrm{CuL}_{2} \mathrm{Zn}\left(\mathrm{NO}_{2}\right)\right.$ $\left.\left(\mathrm{H}_{2} \mathrm{O}\right)\right]^{+}$. These species ought to be formed because of the stepwise ionization of the coligands dicyanamide for the first one and nitrate for the latter. Complexes 3 and $\mathbf{4}$ dissociate into dinuclear heterocomplexes as evident from their mass spectra, the base peaks appear at 555.0591 amu (calcd $555.9127 \mathrm{amu}$ ) and $566.1590 \mathrm{amu}$ (calcd $566.9367 \mathrm{amu}$ ), respectively. In the case of 3 and 4, two hetero-dinuclear moieties are coordinated by weak chloro or nitrito interaction, which disrupts upon solvation to produce the monopositive hetero-dinuclear species.

Theoretical Rationalization of Anion-Dependent Structural Variation. Experimentally, the nuclearity of the complexes formed by the ML CuL depends on the nature of the counter anion (see Figure S8). That is, compound $\mathbf{1}$ is a trinuclear dca (dicyanamide)-bridged polymer, compound 2 $\left(\mathrm{NO}_{3}{ }^{-}\right)$is a trinuclear $\left(\mathrm{Cu}_{2} \mathrm{Zn}\right)$ monomeric complex, and compounds $3\left(\mathrm{Cl}^{-}\right)$and $4\left(\mathrm{NO}_{2}^{-}\right)$are tetranuclear $\left(\mathrm{Cu}_{2} \mathrm{Zn}_{2}\right)$ monomeric complexes. The present DFT study is intended to give some insights into the different nuclearities observed in these complexes. We have focused our analysis to compounds 2-4 because the polymeric nature of $\mathbf{1}$ can be simply rationalized by considering the intrinsic linear geometry of the dicyanamide ligand. For this study, we have fully optimized in $\mathrm{MeOH}$ compounds 2-4 and also the hypothetical tetranuclear complex $2^{\prime}$ (Figure 9d) and trinuclear complexes $3^{\prime}$ and $4^{\prime}$ (Figure 9b,c). The geometric features of the optimized complexes (given in Figure 9) are in good agreement with the X-ray geometries, giving reliability to the level of theory used herein. In Figure 9, we also include the energetic results for the hypothetical transformation of the trinuclear complexes to the tetranuclear ones by the reaction with the appropriate $\mathrm{Zn}$ (II) salt. The transformation of the trinuclear complex into the tetranuclear one is energetically favorable in all cases. However, in the solid state, the tetranuclear complex is only observed for $\mathrm{Cl}^{-}$and $\mathrm{NO}_{2}^{-}$anions (compounds 3 and 4). Therefore, this DFT preliminary analysis is not able to explain the formation of the trinuclear complex 2. Moreover, stoichiometrically, the $\mathrm{CuL} / \mathrm{Zn}$ proportion used $(2: 1)$ is adequate for the formation of the trinuclear assembly. Therefore, the formation of the tetranuclear complexes in 3 and 4 implies that a significant proportion of ML has not reacted.

In general, the rationalization of the nuclearity is complicated because in the solid state, the packing forces and noncovalent interactions with the neighbor molecules are crucial in determining the final solid-state architecture. Therefore, the most-favored nuclearity in the solid state can be different than that in the solution state. The main difference between compounds 2 (trinuclear) and 4 (tetranuclear) is simply the presence of an additional $\mathrm{O}$ atom in the anion (nitrate vs nitrite). This uncoordinated $\mathrm{O}$ atom in $\mathbf{2}$ is pointing to the external part of the complex, perfectly suited for establishing intermolecular interactions. We have analyzed this issue by examining the crystal packing of 2 . We have found that each $\mathrm{NO}_{3}^{-}$anion in 2 establishes an $\mathrm{H}$-bonding interaction with the adjacent molecule. We have computed the interaction energy of the assembly shown in Figure 9 (using the crystallographic coordinates), which is $\Delta E_{4}=-29.8$ $\mathrm{kcal} / \mathrm{mol}$. Interestingly, this interaction energy is able to compensate the $-21.9 \mathrm{kcal} / \mathrm{mol}$ difference between the trinuclear and tetranuclear complexes in $\mathrm{MeOH}$. Keeping in mind the complexity of the intricate combination of forces present in the solid state, we propose that the formation of 
compound 2 (trinuclear) is due to the formation of additional interactions in the solid state that are able to compensate the energetic difference with the tetranuclear one. However, compounds 3 and 4 crystallize in their most stable solution form, indicating that the additional interactions of their hypothetical trinuclear complexes are not able to compensate the energetic differences shown in Figure 9.

Biological Studies. The cytotoxic effect of the investigated metal complexes was examined against HeLa cancer cell lines using the XTT assay; $\mathrm{IC}_{50}$ values are summarized in Table 1 . It

Table 1. $\mathrm{IC}_{50}(\mu \mathrm{M} \pm \mathrm{SD})$ of the Studied Compounds (1-4) against HeLa Cancer Cells, HS-5 and MRC-5 Fibroblasts

$\begin{array}{cccc}\text { complex } & \begin{array}{c}\mathrm{IC}_{50}(\mu \mathrm{M} \pm \mathrm{SD}) \text { in } \\ \text { HeLa cells }\end{array} & \begin{array}{c}\mathrm{IC}_{50}(\mu \mathrm{M} \pm \mathrm{SD}) \text { in } \\ \text { HS-5 cells }\end{array} & \begin{array}{c}\mathrm{IC}_{50}(\mu \mathrm{M} \pm \mathrm{SD}) \\ \text { MRC-5 cells }\end{array} \\ \mathbf{1} & 1.010 \pm 0.020 & 0.120 \pm 0.010 & 0.135 \pm 0.005 \\ \mathbf{2} & 0.967 \pm 0.017 & 0.105 \pm 0.005 & 0.115 \pm 0.005 \\ \mathbf{3} & 0.973 \pm 0.073 & 0.105 \pm 0.005 & 0.120 \pm 0.010 \\ \mathbf{4} & 0.975 \pm 0.025 & 0.094 \pm 0.006 & 0.110 \pm 0.010\end{array}$

is clearly seen that all of the compounds $\mathbf{1 - 4}$ are cytotoxic to the studied cell with $\mathrm{IC}_{50}$ values very close to $1 \mu \mathrm{M}$. From all of these compounds and considering the standard deviation, the most active complex was $\mathbf{3}$ with $\mathbf{2}$ and $\mathbf{4}$ being very close in cytotoxicity. It seems that the structural similarities of the compounds are correlated with very uniform cytotoxic activities.

In general, the compounds reported here showed a much higher cytotoxicity than other reported zinc or copper compounds with similar ligands which were found in the literature to be up to two magnitude orders less cytotoxic than $\mathbf{1 - 4} .^{32-34}$ It seems that the compounds present a higher cytotoxic activity because of the synergic effect of both metal ions $\mathrm{Cu}$ and $\mathrm{Zn}$.

However, we have also carried out the study of the toxicity of 1-4 against normal cells (human bone marrow stroma cells HS-5 and human lung fibroblasts MRC-5); unfortunately, the compounds do not show selectivity against cancer cells on direct comparison with HS-5 or MRC-5. This is maybe due to the mechanism of cytotoxication of the compounds which is likely based on the generation of reactive nitrogen species (RNS) or reactive oxygen species (ROS) because of the NOcontaining ligands of compounds $\mathbf{1 - 4} .^{35,36}$ In this context, normal cells are usually more sensitive to RNS or ROS; therefore, future studies of our research groups will be focused on the design of novel heterometallic compounds including recognizable fragments (such as folates or similar) whose receptors are usually over-expressed in cancer cells. In this context, we think that the compounds may be selective toward cancer cell lines and improve their applicability in future chemotherapeutic treatments (Figure 10).

DNA Interaction Study. The determination of the binding properties of metal complexes with molecules of biological interest can be carried out by a study of the evaluation of the interactions of metallodrugs with DNA by UV-visible absorption spectroscopy. Binding to biomacromolecules is usually associated with modifications of the electronic spectrum of both the compounds, which is interacting or the biomolecule. ${ }^{37}$ It is generally agreed that hypochromism and bathochromism effects mean an intercalation of the metallodrug to DNA associated with strong $\left(\pi \rightarrow \pi^{*}\right)$ stacking interactions between aromatic chromophores of the studied

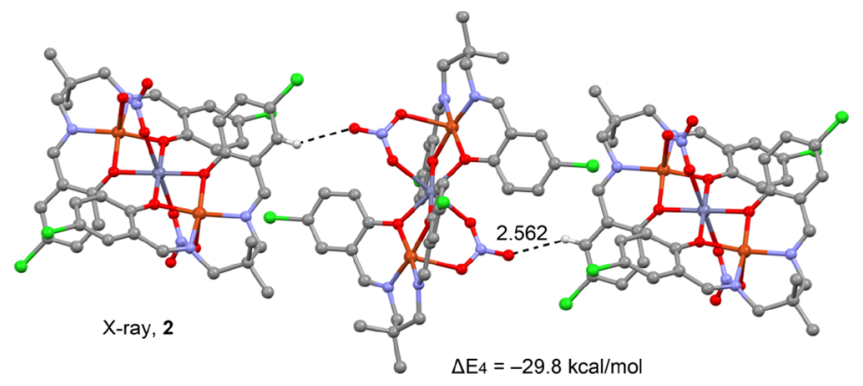

Figure 10. Detail of the H-bonding interaction involving the nitrato ligand in compound $\mathbf{2}$ and the interaction energy of the assembly. Distance in $\AA$.

binding complex and DNA base pairs. ${ }^{38,39}$ Additionally, the hyperchromism effect is usually associated with the interaction of the metal complex with the minor groove of DNA, meaning an unwinding of the DNA double helix leading to unstack and exposure of the nitrogen bases of the DNA chain. ${ }^{40,41}$ As an example, Figure 11 shows the electronic absorption spectra of 3 (one of the most active compounds of the present series) in the absence and presence of FS-DNA.

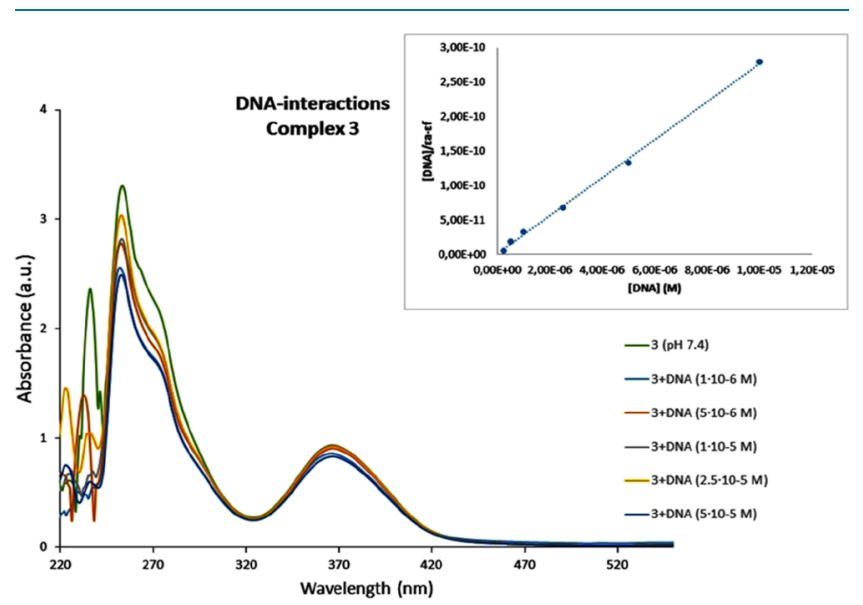

Figure 11. Electronic spectra of complex 3 in a buffer solution $(5 \mathrm{mM}$ Tris- $\mathrm{HCl} / 50 \mathrm{mM} \mathrm{NaCl}$ at $\mathrm{pH}$ 7.4) without and with the addition of different concentrations of FS-DNA. $C($ complex $)=1.5 \times 10^{-5} \mathrm{~mol}$ $\mathrm{L}^{-1}$ and $C(\mathrm{DNA})=0-5 \times 10^{-5} \mathrm{~mol} \mathrm{~L}^{-1}$. Arrow shows that the absorption intensities increase upon increasing the DNA concentration. Inset: Plot of $[\mathrm{DNA}] /\left[\varepsilon_{\mathrm{a}}-\varepsilon_{\mathrm{f}}\right]$ vs $[\mathrm{DNA}]$ for the titration of complex 3 with DNA.

In our study, we have observed that the addition of increasing amounts of DNA to the studied compounds 1-4 leads to hyperchromism (increase of absorption intensity) in the UV-visible absorption spectrum which is a consequence of the minor groove binding of complexes 1-4 to DNA and the unwinding of the DNA double helix. In addition, we observed a slight blue shift in the absorption maximum which confirms the possibility of an electrostatic interaction between the studied compounds $\mathbf{1 - 4}$ and the DNA chain.

In order to compare the binding strengths of the complexes, the intrinsic binding constant, $K_{\mathrm{b}}$, was determined using the following eq $1 .{ }^{42}$

$$
\frac{[D N A]}{\varepsilon_{\mathrm{a}}-\varepsilon_{\mathrm{f}}}=\frac{[\mathrm{DNA}]}{\varepsilon_{\mathrm{b}}-\varepsilon_{\mathrm{f}}}+\frac{1}{K_{\mathrm{b}}\left(\varepsilon_{\mathrm{b}}-\varepsilon_{\mathrm{f}}\right)}
$$


where [DNA] is the concentration of DNA in base pairs, $\varepsilon_{\mathrm{a}}, \varepsilon_{\mathrm{f}}$, and $\varepsilon_{\mathrm{b}}$ correspond to $A_{\mathrm{obs}} /$ [complex], the extinction coefficient of the free complexes, and the extinction coefficient of the complexes in the fully bound form, respectively, and $K_{\mathrm{b}}$ is the intrinsic binding constant. The ratio of slope to intercept in the plot of $[\mathrm{DNA}] /\left(\varepsilon_{\mathrm{a}}-\varepsilon_{\mathrm{f}}\right)$ versus [DNA] gives the value of $K_{\mathrm{b}}$ (inset Figure 11).

Using this method, the intrinsic binding constants of compounds 1-4 were, respectively, of $3.61 \times 10^{4}, 2.92 \times$ $10^{4}, 4.24 \times 10^{4}$, and $2.88 \times 10^{4} \mathrm{M}^{-1}$, observing that they are all in the same order of magnitude. The highest binding constant is found for compound 3 which again, as in the case of the study of the cytotoxic activity, seems to have a slightly higher binding ability to DNA.

Fluorescence $M B$ Experiments. Additional fluorescence experiments were carried out to get more insights on the mechanism of interaction of complex 3 . Thus, a competitive measurement in the presence of the typical intercalator $\mathrm{MB}$ was carried out. It is well known that MB is a planar molecule that has usually been utilized for dying in different specific biological assays. ${ }^{43} \mathrm{MB}$ usually inserts into each of the DNA strands because of its positive charge which can electrostatically interact with DNA anions giving intercalating bonds which are irreversible. This makes that the emission and absorption spectra of the $\mathrm{MB}$ adducts highly depend on the type of the bond. ${ }^{44,45}$

Thus, a fluorescence method was carried out to investigate the interaction of complex 3 with an adduct DNA-MB $([\mathrm{DNA}] /[\mathrm{MB}]=10)$ using increasing concentrations of the metallodrug. After the addition of 3 , the emission intensities of the adducts were recorded, observing that the addition of 3 seems to quench the $\mathrm{MB}$ emission intensity, so that the emission spectra of MB-DNA solutions decreased considerably in the presence of increasing amounts of 3 (Figure 12). This is an indication of a possible insertion of the complex into the DNA double helix, which is associated with an intercalative

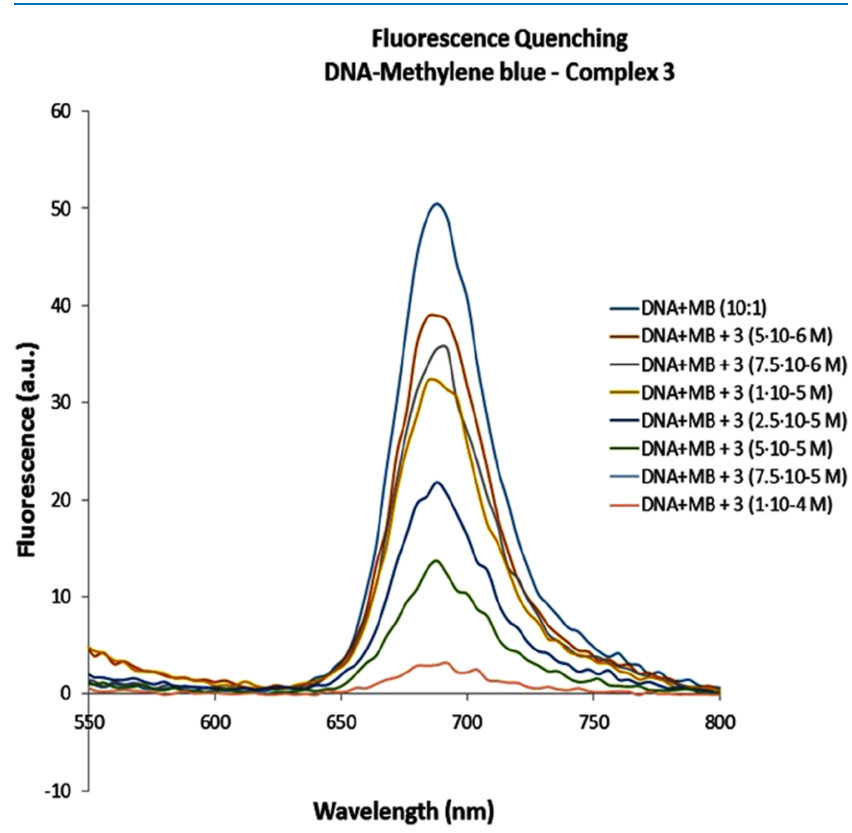

Figure 12. Fluorescence emission spectra for MB-DNA adducts in Tris-buffer in the absence and presence of increasing concentrations of 3. binding behavior as observed in the previous studies using UV spectroscopy.

Protein Binding Studies. Interactions with BSA Determined by Absorption UV-Spectroscopy. Albumin is a very important transport protein which is usually contributing to the transport of some external agents to the interior of the cells. Thus, structural changes in the mechanism of complex formation in the donor-acceptor system characteristic of metallodrug interactions with different proteins such as albumin can be studied by UV-visible absorption spectroscopy. This method is very effective to determine changes in the absorption bands to determine and understand the interactions of metal complexes with proteins. ${ }^{46}$ The absorption spectrum of BSA has two simple bands at 220 and $280 \mathrm{~nm}$ because of the absorption peak of BSA polypeptide structure and the different aromatic amino acids which can be found in the protein structure (tryptophan, tyrosine, and phenylalanine). In this context, as the transport of the metallodrug might be one of the processes for a hypothetical cell internalization of the complex, the interaction between 3 and the transport protein albumin was determined on the basis of the UV-visible absorption spectra.

The structural changes in BSA are usually indicated by variations in the absorption band between 220 and $240 \mathrm{~nm}$; in addition, changes at $280 \mathrm{~nm}$ are usually induced by changes in the sub-environments around BSA amino acids. For complex 3, the BSA absorption intensity significantly decreased and in some cases almost disappears in the range of 220-240 nm upon addition of increasing amounts of the metallodrug (Figure 13). As a consequence of the changes in the protein

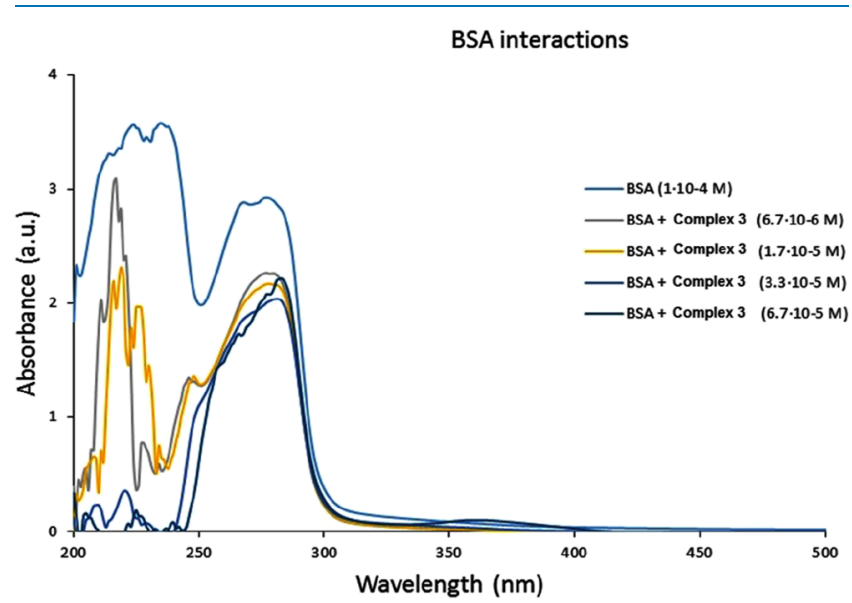

Figure 13. UV-visible absorption spectra for BSA in Tris-buffer in the absence and presence of increasing concentrations of 3 .

structure, it is possible to observe a softer change on the maximum absorption at $280 \mathrm{~nm}$, which is indicating clear structural changes with the $\alpha$-helix of the primary substructure of the protein which is probably a consequence of a specific interaction between 3 and BSA. ${ }^{47}$ These results indicated a high interaction of 3 with albumin, confirming that this transport protein may be one of the possible biological targets inducing the transport of this complex inside cells.

BSA Tryptophan Quenching. BSA fluorescence is generally due to tryptophan (Trp) of BSA located on the surface of domain, Trp-213 of the hydrophobic pocket of domain II, and phenyl alanine (Phe) residues. Usually, solutions of BSA present a fluorescence emission at $345 \mathrm{~nm}$ which is due to 
tryptophan residues, upon excitation at $285 \mathrm{~nm}$. The fluorescence intensity of the peak $345 \mathrm{~nm}$ decreased upon increasing concentrations of metal complex which confirms the conformational changes in the secondary structure of the protein due to interaction with complex 3 which quenches its intrinsic fluorescence. The quenching mechanism between complex 3 and BSA is described by the linear Stern-Volmer equation (eq 2).

$$
\frac{F_{0}}{F}=1+K_{\mathrm{sv}}[\mathrm{Q}]=1+K_{\mathrm{q}} \tau_{0}[\mathrm{Q}]
$$

where $F_{0}$ and $F$ are BSA fluorescence intensities in the absence and presence of metal complex, respectively, and $K_{\mathrm{q}}, K_{\mathrm{sv}}, \tau_{0}$, and $[\mathrm{Q}]$ are the BSA quenching rate constant, the dynamic quenching constant, the average BSA lifetime in the absence of quencher (estimated in $10^{-8} \mathrm{~s}^{-1}$ ) and the quencher concentration, respectively.

Using this method, we were able to determine $K_{\mathrm{sv}}$ for complex 3 which was $1.02 \times 10^{12} \mathrm{M}^{-1} \mathrm{~s}^{-1}$ which is in the range for other metal-based drugs. ${ }^{48}$ These results are in agreement with a static quenching interaction as reported previously for similar compounds. ${ }^{48}$

Determination of Binding Constant BSA-3 and the Number of Binding Sites. For the determination of the binding constant $\left(K_{\mathrm{a}}\right)$ and the number of binding sites $(n)$ for the static quenching interaction, assuming similar and independent binding sites in the biomolecule, the following equation (eq 3 ) is governing the fluorescence emission

$$
\log \frac{\left(F_{0}-F\right)}{F}=\log K_{\mathrm{a}}+n \log [\mathrm{Q}]
$$

where $n$ is the average number of binding sites per albumin molecule and $K_{\mathrm{a}}$ is the binding constant in the protein complex interaction. For the system complex $3-$ BSA, $K_{\mathrm{a}}$ and $n$ values at room temperature were $3.31 \times 10^{3} \mathrm{M}^{-1}$ and 0.78 , respectively. These results show that complex 3 has a moderate binding constant ${ }^{44}$ and that 3 is implied in only a single binding site in each albumin.

\section{CONCLUSIONS}

The applications of heterometallic compounds are majorly being concentrated over the branch of magnetism. Numerous researchers are busy cultivating the magnetic properties in order to develop SMM and other magnetic devices, becoming the route over-saturated while leaving the biomedical applications untouched. This furnishes us the sufficient opportunity to investigate the clinical values of these heterometallic systems by employing them in different biological tests as therapeutic drugs. In order to carry out the job, we have taken two different biorelevant transition metals copper and zinc to incorporate in a single framework. Four different heterometallic complexes were obtained from these systems by varying the corresponding coligands. Strikingly, all of them have found to show high biomedical properties. The complexes demonstrate moderate cytotoxicity against HeLa cancer cells as evidenced by the XTT assay. Also, they provide high DNA binding capability through intercalative mechanism, and finally, they can be successfully transported as a drug to cells as verified by the BSA protein transport mechanism. In the latter two cases, fluorescence quenching studies have been carried out to get insight into the detailed mechanistic pathways. All of these experimental results show that the heterometallic complexes exhibit high cytotoxicity and binding constants and their values are quite a fold increase with respect to similar homometallic complexes. Finally, from this study, we are able to conclude that heterometallic complexes have better biomedical values and can be constructed as therapeutic drugs, advancement of their clinical properties possibly owing to the better interaction (synergic effect) of different metals with a single biological target.

\section{EXPERIMENTAL DETAILS}

Physical Methods and Materials. 5-Chloro salicylaldehyde and $\mathrm{N}, \mathrm{N}$-dimethylethylenediamine were purchased from Sigma-Aldrich. Reagent-graded organic reagents and solvents are used for synthesis required during this entire project. They were purchased from marketable resources and further distilled before use. Milli-Q graded water had been used in all physical measurements and experiments. Elemental analyses (carbon, hydrogen, and nitrogen) were performed by a PerkinElmer $240 \mathrm{C}$ analyzer, and for recording infrared spectra, Shimadzu FTIR-8400S and PerkinElmer Spectrum Express Version 1.03 were used $\left(4000-400 \mathrm{~cm}^{-1}\right)$ at $28{ }^{\circ} \mathrm{C}$ using $\mathrm{KBr}$ pellets as mediums. The observation of the UV-visible spectra was carried out by a Shimadzu UV-2450PC spectrophotometer equipped with multiple cell-holders and thermostat.

The preparation and composition using the stepwise technique are discussed elaborately in the Supporting Information

X-ray Data Collection and Structure Determination. A Bruker Smart Apex diffractometer (Mo $\mathrm{K} \alpha$ radiation, $\lambda=$ $0.71073 \AA$ ) equipped with a charge-coupled device was utilized to collect the intensity data for crystal structure analyses of $\mathrm{ML}$ and all of the compounds 1-4 at room temperature. For cell refinement, indexing, and scaling of the data sets, the program Bruker Smart Apex and Bruker Saint packages ${ }^{49}$ were used. All structures were solved by direct methods and subsequent Fourier analyses ${ }^{50}$ and refined by the full-matrix least-squares method based on $F^{2}$ with all observed reflections. ${ }^{50}$ Bridging nitrate anion in compound $\mathbf{2}$ was found disordered on two positions, refined at half occupancy with isotropic thermal ellipsoids. In addition, in complex 2 , the $\Delta F$ map revealed the presence of a residual interpreted as oxygen water at half occupancy. All hydrogen atoms were placed at calculated positions and included in final cycles of refinement. $\mathrm{H}$ atoms of the water molecule in $\mathbf{2}$ at half occupancy were not located. WinGX System, Ver 2013.3 ${ }^{51}$ was employed to perform all of the required calculations. Crystal data and details of refinements are given in Table S1.

\section{ASSOCIATED CONTENT}

\section{Supporting Information}

The Supporting Information is available free of charge on the ACS Publications website at DOI: 10.1021/acsomega.8b01260.

CCDC 1836372-1836376 contain the supplementary crystallographic data for this paper. These data can be obtained free of charge via www.ccdc.cam.ac.uk/data request/cif, or by emailingdata_request@ccdc.cam.ac. uk, or by contacting The Cambridge Crystallographic Data Centre, 12 Union Road, Cambridge CB2 1EZ, UK; Fax: +44 1223 336033; experimental section; and crystallographic data and details of refinements, FTIR 
spectra, UV-vis spectra, and coordination bond lengths and angles for ML and complexes 1-4 (PDF)

Crystallographic data of $\mathbf{1}$ (CIF)

Crystallographic data of $\mathbf{2}$ (CIF)

Crystallographic data of 3 (CIF)

Crystallographic data of 4 (CIF)

Crystallographic data of ML (CIF)

\section{AUTHOR INFORMATION}

\section{Corresponding Authors}

*E-mail: santiago.gomez@urjc.es (S.G.-R).

*E-mail: dasdebasis2001@yahoo.com (D.D.).

ORCID

Rafael Peláez: 0000-0003-1433-1612

Antonio Bauza: 0000-0002-5793-781X

Antonio Frontera: 0000-0001-7840-2139

Debasis Das: 0000-0003-4570-7168

\section{Notes}

The authors declare no competing financial interest.

\section{ACKNOWLEDGMENTS}

The authors wish to thank the Univ. of Calcutta for providing single-crystal X-ray diffractometer (under DST-FIST). I.M. is thankful to UGC, India [UGC/689/JrFellow(Sc) (Up gradation)], for providing fellowship. Authors from Rey Juan Carlos University like to thank the financial support of the Ministerio de Economía y Competitividad (Spain) and FEDER (grant no. CTQ2015-66164-R). We are thankful to Dr. Sumi Ganguly, Assistant Professor in Chemistry, Sister Nibedita Govt. General Degree College for Girls, Kolkata, India, for help in structure solution.

\section{REFERENCES}

(1) Ghosh, S.; Ida, Y.; Ishida, T.; Ghosh, A. Linker StoichiometryControlled Stepwise Supramolecular Growth of a Flexible Cu2 Tb Single Molecule Magnet from Monomer to Dimer to OneDimensional Chain. Cryst. Growth Des. 2014, 14, 2588-2598.

(2) Biswas, S.; Saha, R.; Ghosh, A. Copper(II)-Mercury(II) Heterometallic Complexes Derived from a Salen-Type Ligand: A New Coordination Mode of the Old Schiff Base Ligand. Organometallics 2012, 31, 3844-3850.

(3) Kara, H.; Azizoglu, A.; Karaoglu, A.; Yahsi, Y.; Gungor, E.; Caneschi, A.; Sorace, L. Synthesis, crystal structure, magnetic properties and computational study of a series of cyano-bridged MnIII-FeIII complexes. Cryst. Eng. Comm. 2012, 14, 7320.

(4) Mahapatra, P.; Drew, M. G. B.; Ghosh, A. Variations of Structures and Phenoxazinone Synthase-like Activity of the Complexes Based on (CuII)2MnII Node and Dicyanamide Spacer. Cryst. Growth Des. 2017, 17, 6809-6820.

(5) Pasatoiu, T. D.; Tiseanu, C.; Madalan, A. M.; Jurca, B.; Duhayon, C.; Sutter, J. P.; Andruh, M. Study of the Luminescent and Magnetic Properties of a Series of Heterodinuclear [ZnIILnIII] Complexes. Inorg. Chem. 2011, 50, 5879-5889.

(6) Maxim, C.; Sorace, L.; Khuntia, P.; Madalan, A. M.; Kravtsov, V.; Lascialfari, A.; Caneschi, A.; Journaux, Y.; Andruh, M. A missing highspin molecule in the family of cyanido-bridged heptanuclear heterometal complexes, [(LCuII)6FeIII $(\mathrm{CN}) 6] 3+$, and its CoIII and CrIII analogues, accompanied in the crystal by a novel octameric water cluster. Dalton Trans. 2010, 39, 4838.

(7) Binnemans, K.; Görller-Walrand, C. Lanthanide-Containing Liquid Crystals and Surfactants. Chem. Rev. 2002, 102, 2303-2346.

(8) Edder, C.; Piguet, C.; Bünzli, J.-C. G.; Hopfgartner, G. HighSpin Iron(ii) as a Semitransparent Partner for Tuning Europium(iii)
Luminescence in Heterodimetallic d-f Complexes. Chem.-Eur. J. 2001, 7, 3014-3024.

(9) Glover, P. B.; Ashton, P. R.; Childs, L. J.; Rodger, A.; Kercher, M.; Williams, R. M.; De Cola, L.; Pikramenou, Z. Hairpin-Shaped Heterometallic Luminescent Lanthanide Complexes for DNA Intercalative Recognition. J. Am. Chem. Soc. 2003, 125, 9918-9919.

(10) Ma, D.-L.; He, H.-Z.; Leung, K.-H.; Chan, D. S.-H.; Leung, C.H. Bioactive Luminescent Transition-Metal Complexes for Biomedical Applications. Angew. Chem., Int. Ed. 2013, 52, 7666-7682.

(11) Vellaisamy, K.; Li, G.; Ko, C.-N.; Zhong, H.-J.; Fatima, S.; Kwan, H.-Y.; Wong, C.-Y.; Kwong, W.-J.; Tan, W.; Leung, C.-H.; Ma, D.-L. Cell Imaging of Dopamine Receptor using Agonist Labeling Iridium(III) Complex. Chem. Sci. 2018, 9, 1119-1125.

(12) Lu, L.; Shiu-Hin Chan, D.; Kwong, D. W. J.; He, H.-Z.; Leung, C.-H.; Ma, D.-L. Detection of Nicking Endonuclease Activity using a G-Quadruplex-Selective Luminescent Switch-on Probe. Chem. Sci. 2014, 5, 4561-4568.

(13) Burke, C. S.; Byrne, A.; Keyes, T. E. Targeting Photoinduced DNA Destruction by $\mathrm{Ru}$ (II) Tetraazaphenanthrene in Live Cells by Signal Peptide. J. Am. Chem. Soc. 2018, 140, 6945-6955.

(14) Boyle, K. M.; Barton, J. K. A Family of Rhodium Complexes with Selective Toxicity toward Mismatch Repair-Deficient Cancers. J. Am. Chem. Soc. 2018, 140, 5612-5624.

(15) Wang, W.; Vellaisamy, K.; Li, G.; Wu, C.; Ko, C.-N.; Leung, C.H.; Ma, D.-L. Development of a Long-Lived Luminescence Probe for Visualizing $\beta$-Galactosidase in Ovarian Carcinoma Cells. Anal. Chem. 2017, 89, 11679-11684.

(16) Deng, H.; Hentati, A.; Tainer, J.; Iqbal, Z.; Cayabyab, A.; Hung, W.; Getzoff, E.; Hu, P.; Herzfeldt, B.; Roos, R. Amyotrophic lateral sclerosis and structural defects in $\mathrm{Cu}, \mathrm{Zn}$ superoxide dismutase. Science 1993, 261, 1047-1051.

(17) Valentine, J. S.; Doucette, P. A.; Zittin Potter, S. Copper-Zinc Superoxide Dismutase and Amyotrophic Lateral Sclerosis. Annu. Rev. Biochem. 2005, 74, 563-593.

(18) Marzano, C.; Pellei, M.; Tisato, F.; Santini, C. Copper Complexes as Anticancer Agents. Anti-Cancer Agents Med. Chem. 2009, 9, 185-211.

(19) Santini, C.; Pellei, M.; Gandin, V.; Porchia, M.; Tisato, F.; Marzano, C. Advances in Copper Complexes as Anticancer Agents. Chem. Rev. 2014, 114, 815-862.

(20) Ali, H. A.; Shalash, A. M.; Akkawi, M.; Jaber, S. Synthesis, Characterization and In Vitro Biological Activity of New Zinc(II) Complexes of the Nonsteroidal Anti-Inflammatory Drug Sulindac and Nitrogen-Donor Ligands. Appl. Organometal. Chem 2017, 31, 3772.

(21) Sanyal, R.; Zhang, X.; Kundu, P.; Chattopadhyay, T.; Zhao, C.; Mautner, F. A.; Das, D. Mechanistic Implications in the Phosphatase Activity of Mannich-Based Dinuclear Zinc Complexes with Theoretical Modeling. Inorg. Chem. 2015, 54, 2315-2324.

(22) Rahbari, R.; Sheahan, T.; Modes, V.; Collier, P.; Macfarlane, C.; Badge, R. M. A Novel L1 Retrotransposon Marker for HeLa cell line Identification. BioTechniques 2009, 46, 277-284.

(23) Ahlrichs, R.; Bär, M.; Häser, M.; Horn, H.; Kölmel, C. Electronic Structure Calculations on Workstation Computers: The Program System Turbomole. Chem. Phys. Lett. 1989, 162, 165-169.

(24) Klampt, A. The COSMO and COSMO-RS Solvation Models. Wiley Interdiscip. Rev.: Comput. Mol. Sci. 2011, 1, 699.

(25) Marmur, J. A Procedure for the Isolation of Deoxyribonucleic Acid from Micro-organisms. J. Mol. Biol. 1961, 3, 208.

(26) Reichmann, M. E.; Rice, S. A.; Thomas, C. A.; Doty, P. A Further Examination of the Molecular Weight and Size of Desoxypentose Nucleic Acid. J. Am.Chem. Soc. 1954, 76, 3047-3053.

(27) Mondal, S.; Mandal, S.; Jana, A.; Mohanta, S. Dinuclear, starshaped tetranuclear and trinuclear-based two-dimensional metal complexes derived from a less investigated Schiff base ligand: Syntheses, crystal structures and spectroscopic correlation. Inorg. Chim. Acta 2014, 415, 138-145.

(28) Ülkü, D.; Tatar, L.; Atakol, O.; Durmuş, S. Bis\{( $\mu$-nitrato $)[\mu$ bis(salicylidene)-1,3-propanediaminato]copper(II)\}zinc(II). Acta Crystallogr. Sect. C. 1999, 55, 1652-1654. 
(29) Fukuhara, C.; Tsuneyoshi, K.; Matsumoto, N.; Kida, S.; Mikuriya, M.; Mori, M. Synthesis and characterization of trinuclear Schiff-base complexes containing sulphur dioxide or hydrogensulphite ions as bridging groups. Crystal structure of $[\mathrm{Zn}\{(\mu-\mathrm{CH} 3 \mathrm{CO} 2)$ $\left(\right.$ salpd- $\left.\left.\left.\mu-\mathrm{O}, \mathrm{O}^{\prime}\right) \mathrm{Cu}\right\} 2\right][\mathrm{salpd}=$ propane-1,3-diylbis(salicylideneiminate)]. J. Chem. Soc. Dalton Trans. 1990, 3473-3479. (30) Das, L. K.; Park, S.-W.; Cho, S. J.; Ghosh, A. An unprecedented "linear-bent" isomerism in tri-nuclear Cu2IIZnII complexes with a salen type di-Schiff base ligand. Dalton Trans. 2012, 41, 11009.

(31) Addison, A. W.; Rao, T. N.; Reedijk, J.; van Rijn, J.; Verschoor, G. C. Synthesis, structure, and spectroscopic properties of copper(II) compounds containing nitrogen-sulphur donor ligands; the crystal and molecular structure of aqua[1,7-bis( $\mathrm{N}$-methylbenzimidazol-2' yl)-2,6-dithiaheptane]copper(II) perchlorate. J. Chem. Soc., Dalton Trans. 1984, 1349-1356.

(32) Koley, M. K.; Duraipandy, N.; Kiran, M. S.; Varghese, B.; Manoharan, P. T.; Koley, A. P. DNA Binding and Cytotoxicity of Some $\mathrm{Cu}(\mathrm{II}) / \mathrm{Zn}$ (II) Complexes Containing a Carbohydrazone Schiff base Ligand along with 1,10-phenanthroline as a Coligand. Inorg. Chim. Acta 2017, 466, 538-550.

(33) Kumar, K. S.; Chityala, V. K.; Subhashini, N. J. P.; Prashanthi, Y.; Shivaraj. Synthesis, Characterization, and Biological and Cytotoxic Studies of Copper(II), Nickel(II), and Zinc(II) Binary Complexes of 3-Amino-5-methyl Isoxazole Schiff Base. ISRN Inorg. Chem. 2013, 2013, 562082.

(34) Shi, Y.; Toms, B. B.; Dixit, N.; Kumari, N.; Mishra, L.; Goodisman, J.; Dabrowiak, J. C. Cytotoxicity of $\mathrm{Cu}(\mathrm{II})$ and $\mathrm{Zn}(\mathrm{II})$ 2,2'-Bipyridyl Complexes: Dependence of IC50on Recovery Time. Chem. Res. Toxicol. 2010, 23, 1417-1426.

(35) Adeniyi, A. A.; Ajibade, P. A. The Anticancer Activities of Some Nitrogen Donor Ligands Containing bis-Pyrazole, Bipyridine, and Phenanthroline Moiety Using Docking Methods. Bioinor. Chem. and App. 2018, 2018, 1-12.

(36) Alvisi, G.; Poon, I.; Jans, D. Tumor-specific Nuclear Targeting: Promises for Anti-Cancer Therapy? Drug Resistance Updates 2006, 9, 40-50.

(37) Long, E. C.; Barton, J. K. On Demonstrating DNA Intercalation. Acc. Chem. Res. 1990, 23, 271-273.

(38) Chen, Z.-F.; Shi, Y.-F.; Liu, Y.-C.; Hong, X.; Geng, B.; Peng, Y.; Liang, H. TCM Active Ingredient Oxoglaucine Metal Complexes: Crystal Structure, Cytotoxicity, and Interaction with DNA. Inorg. Chem. 2012, 51, 1998-2009.

(39) Abedi, A.; Lighvan, Z. M.; Ostad, S. N. Cytotoxicity and DNA/ BSA Binding Ability of Copper(II) Complexes with Dimethylbithiazole. Monatsh. Chem./Chem. Monthly. 2016, 147, 1651-1658.

(40) Tjioe, L.; Meininger, A.; Joshi, T.; Spiccia, L.; Graham, B. Efficient Plasmid DNA Cleavage by Copper(II) Complexes of 1,4,7Triazacyclononane Ligands Featuring Xylyl-Linked Guanidinium Groups. Inorg. Chem. 2011, 50, 4327-4339.

(41) Kumar, P.; Gorai, S.; Kumar Santra, M.; Mondal, B.; Manna, D. DNA Binding, Nuclease Activity and Cytotoxicity Studies of $\mathrm{Cu}$ (II) Complexes of Tridentate ligands. Dalton Trans. 2012, 41, 7573.

(42) Pyle, A. M.; Rehmann, J. P.; Meshoyrer, R.; Kumar, C. V.; Turro, N. J.; Barton, J. K. Mixed-ligand complexes of ruthenium(II): factors governing binding to DNA. J. Am.Chem. Soc. 1989, 111, 3051-3058.

(43) Meric, B.; Kerman, K.; Ozkan, D.; Kara, P.; Erensoy, S.; Akarca, U. S.; Mascini, M.; Ozsoz, M. Electrochemical DNA Biosensor for the Detection of TT and Hepatitis B Virus from PCR Amplified Real Samples by Using Methylene Blue. Talanta 2002, 56, 837-846.

(44) Bordbar, M.; Tabatabaee, M.; Yeganeh Faal, A.; Mehri Lighvan, Z.; Fazaeli, R. DNA Binding Properties of Water-Soluble Mixed Ligand Nickel(II) Complex with Calf-thymus DNA Using Different Instrumental Methods. Met.-Org. Nano-Metal. Chem. 2015, 45, 18821888.

(45) Shahsavar, F.; Bozorgmehr, M.; Mirzadegan, E.; Abedi, A.; Mehri Lighvan, Z.; Mohammadi, F.; Safari, N.; Amani, V.; Zarnani, A.-H. A Novel Platinum-Based Compound with Preferential
Cytotoxic Activity against a Panel of Cancer Cell Lines. Anticancer Agents Med. Chem. 2016, 16, 393-403.

(46) Sathyadevi, P.; Krishnamoorthy, P.; Butorac, R. R.; Cowley, A. H.; Dharmaraj, N. Synthesis of Novel Heterobimetallic Copper(I) Hydrazone Schiff Base Complexes: A Comparative Study on the Effect of Heterocyclic Hydrazides towards Interaction with DNA/ Protein, free Radical Scavenging and Cytotoxicity. Metallomics 2012, 4, 498.

(47) Li, X.-W.; Li, X.-J.; Li, Y.-T.; Wu, Z.-Y.; Yan, C.-W. Syntheses and structures of new trimetallic complexes bridged by N-(5-chloro-2hydroxyphenyl)- $\mathrm{N}^{\prime}$-[3-(dimethylamino)propyl]oxamide: Cytotoxic activities, and reactivities towards DNA and protein. J. Photochem. Photobiol. B. 2013, 118, 22-32.

(48) Sedighipoor, M.; Kianfar, A. H.; Kamil Mahmood, W. A.; Azarian, M. H. Synthesis and Electronic Structure of Novel Schiff Bases $\mathrm{Ni} / \mathrm{Cu}$ (II) Complexes: Evaluation of DNA/Serum Protein Binding by Spectroscopic Studies. Polyhedron 2017, 129, 1-8.

(49) SMART, SAINT. Software Reference Manual; Bruker AXS Inc.: Madison, WI, 2000.

(50) Sheldrick, G. M. A short history ofSHELX. Acta Crystallogr 2008, 64, 112-122.

(51) Farrugia, L. J. WinGXandORTEP for Windows: an update. J. Appl. Crystallogr. 2012, 45, 849-854. 